\title{
JNPH
}

Volume 6 No. 1 (April 2018)

(C) The Author(s) 2018

\section{EFEKTIVITAS PENGOLAHAN LIMBAH CAIR INDUSTRI TAHU DENGAN METODE AERASI UNTUK MENURUNKAN KADAR BOD}

\author{
THE EFFECTIVENESS OF LIQUID WASTE TREATMENT WITH TOFU INDUSTRY \\ AERATION METHODS TO LOWER BOD LEVELS
}

\author{
RIANG ADEKO DAN AGUS WIDADA \\ POLITEKNIK KESEHATAN KEMENTERIAN KESEHATAN BENGKULU, JURUSAN \\ KESEHATAN LINGKUNGAN,JALAN INDRAGIRI NOMOR 3 \\ PADANG HARAPAN BENGKULU \\ EMAIL: keslingpoltek@gmail.com
}

\begin{abstract}
ABSTRAK
Industri tahu adalah industri pangan yang menggunakan bahan baku dari kacang kedelai, dimana tahu adalah salah satu hasil olahan dari ekstrak kedelai yang dilakukan dengan penambahan asam cuka. Limbah cair tahu yang di hasilkan banyak mengandung padatan tersuspensi maupun terlarut, jika limbah tahu ini langsung dibuang ke badan air akan mempengaruhi kelangsungan hidup biota di suangai dan mencemari lingkungan sekitar, bila ini dibiarkan, limbah akan berubah warna menjadi colat kehitaman dan berbau busuk, juga akan mencemari tanah dan mengganggu makhluk hidup disekitarnya.Jenis penelitian quasi experiment, desain penelitian pre-post test. Alat dan bahan kontainer plastik 90 lt, aerator, pompa air, selang, media pecahan batu bata. Penelitian ini dilakukan dengan variasi ketebalan media $10 \mathrm{Cm}, 20 \mathrm{Cm}, 30 \mathrm{Cm}$ dan lama waktu kontak 3 hari, 6 hari dan 9 hari. Pengukuran parameter BOD dilakukan sebelum dilakukan perlakuan dan setelah perlakuan pada hari ketiga, keenam dan kesembilan. Hasil pengukuran dibandingkan dengan baku mutu air limbah berdasarkan PerMenLHRI No. 15 Tahun 2014. Data dianalisis secara univariat dan di sajikan secara deskriptif.Hasil Uji Statistik Kruskall Wallis didapatkan tidak ada perbedaan kadar BOD ketebalan media pecahan batu bata $10 \mathrm{Cm}, 20 \mathrm{Cm}$, dan $30 \mathrm{Cm}$ baik pada hari ke 3, 6 dan 9 . Penurunan BOD yang paling efektif pada ketebalan $10 \mathrm{Cm}$ hari ke 6 terjadi penurunan sebesar $64,27 \%$.Saran : Penelitian ini dapat dijadikan salah satu alternatif pengolahan limbah tahu dan penelitian ini dapat dilanjutkan dengan penambahan bakteri yang spesifik untuk meningkatkan efektifitasnya.
\end{abstract}

Kata Kunci: Aerasi, biofilter, limbah

\begin{abstract}
The tofu industry is a food industry that uses raw materials from soybeans, where tofu is one of the processed products of soy extract done with the addition of vinegar. The liquid waste of tofu which is produced contains many suspended and dissolved solids, if the tofu waste is directly discharged into the body of water will affect the survival of biota in suangai and pollute the environment, if this is left, the waste will change color into black and foul smelling colat, also will pollute the soil and disrupt the living things around it.Jenis penelitian quasi experiment, desain penelitian pre-post test. Alat dan bahan kontainer plastik 90 lt, aerator, pompa air, selang,
\end{abstract}


media pecahan batu bata. Penelitian ini dilakukan dengan variasi ketebalan media $10 \mathrm{Cm}, 20$ $\mathrm{Cm}, 30 \mathrm{Cm}$ dan lama waktu kontak 3 hari, 6 hari dan 9 hari. Pengukuran parameter BOD dilakukan sebelum dilakukan perlakuan dan setelah perlakuan pada hari ketiga, keenam dan kesembilan. Hasil pengukuran dibandingkan dengan baku mutu air limbah berdasarkan PerMenLHRI No. 15 Tahun 2014. Data dianalisis secara univariat dan di sajikan secara deskriptif.Hasil Uji Statistik Kruskall Wallis didapatkan tidak ada perbedaan kadar BOD ketebalan media pecahan batu bata $10 \mathrm{Cm}, 20 \mathrm{Cm}$, dan $30 \mathrm{Cm}$ baik pada hari ke 3, 6 dan 9 . Penurunan BOD yang paling efektif pada ketebalan $10 \mathrm{Cm}$ hari ke 6 terjadi penurunan sebesar 64,27 \%.Penelitian ini dapat dijadikan salah satu alternatif pengolahan limbah tahu dan penelitian ini dapat dilanjutkan dengan penambahan bakteri yang spesifik untuk meningkatkan efektifitasnya.

Keywords: Aeration, biofilter, waste

\section{PENDAHULUAN}

Sumber pencemaran lingkungan diantaranya berasal dari air, tanah, dan udara. Salah satu faktor pencemaran tersebut disebabkan oleh limbah yang berasal dari domestik, pertanian, industri, dan sebagainya dalam hal ini limbah industri tahu. Dampak yang ditimbulkan oleh pencemaran bahan organik limbah industri tahu adalah gangguan terhadap kehidupan biotik. Turunnya kualitas air perairan akibat meningkatnya kandungan bahan organik (Herlambang, 2002).

Proses pengolahan air limbah tahu menggunakan batu bata sebagai media tumbuhnya biofilm merupakan cara untuk mengatasi limbah tahu sehingga kadar BOD dapat menurun sesuai dengan baku mutu yang dipersyaratkan oleh permen -LH No: 15-th2008 usaha/kegiatan pengelolaan kedelai, BOD kadar yang di perbolehkan $150 \mathrm{ml} / \mathrm{l}$.

\section{JENIS DAN RANCANGAN PENELITIAN}

Jenis penelitian yang digunakan dalam penelitian ini adalah jenis penelitian eksperimen semu (quasi experiment) yaitu penelitian yang bertujuan untuk menyelidiki kemungkinan ada hubungan sebab akibat dengan cara memberi perlakuan pada satu kelompok perlakuan. Dengan menggunakan desain rancangan penelitian "pre-post test" dimana sebelum melakukan pengolahan dan sesudah melakukan pengolahan.

Lokasi penelitian pada air limbah industri tahu di jalan Merapi Kelurahan
Kebun Tebeng diteliti di bengkel kerja (Workshop) Jurusan Kesehatan Lingkungan Poltekkes Kemenkes Bengkulu dengan alokasi waktu penelitian selama 2 bulan.

\section{HASIL PENELITIAN}

Penelitian ini dilakukan di bengkel kerja (Workshop) Jurusan Kesehatan Lingkungan pada bulan Oktober sampai dengan November 2016, bertujuan untuk mengetahui penurunan kadar BOD.

Hasil pengukuran kadar BOD pada berbagai ketebalan media dan lama kontak disajikan dalam bentuk tabel dan dianalisis secara univariat

Tabel 1 Rata-rata Kadar BOD Sebelum dan Sesudah Proses Aerasi dan Biofiltrasi

\begin{tabular}{lcccc}
\hline $\begin{array}{l}\text { Perlakua Hari Ke } \\
\text { n/Ketebal } \\
\text { an }\end{array}$ & $\begin{array}{c}\text { Kadar } \\
\text { BOD } \\
(\mathrm{mg} / \mathrm{l})\end{array}$ & $\begin{array}{c}\text { Jml } \\
\text { penurunan }\end{array}$ & $\begin{array}{c}\% \\
\text { Penurunan }\end{array}$ \\
\hline & $\begin{array}{l}\text { Sebelum } \\
\text { perlakua } \\
\mathrm{n}\end{array}$ & 229,5 & - & - \\
& & & \\
\hline $10 \mathrm{Cm}$ & Tiga & 148,5 & 81 & 35,29 \\
\cline { 2 - 5 } & Enam & 82 & 147,5 & 64,27 \\
\cline { 2 - 5 } & Sembilan & 105,5 & 124 & 54,03 \\
\hline $20 \mathrm{Cm}$ & Tiga & 127 & 102,5 & 44,66 \\
\cline { 2 - 5 } & Enam & 78 & 151,5 & 66,04 \\
\cline { 2 - 5 } & Sembilan & 66 & 163,5 & 71,24 \\
\hline $30 \mathrm{Cm}$ & Tiga & 141 & 88,5 & 38,56 \\
\cline { 2 - 5 } & Enam & 85 & 144,5 & 62,96 \\
\cline { 2 - 5 } & Sembilan & 121 & 108,5 & 47,28 \\
\hline
\end{tabular}


Berdasarkan tabel 1 kadar BOD sebelum perlakuan adalah $229,5 \mathrm{mg} / 1$, dari 3 perlakuan tersebut yang paling tertinggi penurunannya adalah terletak pada perlakuan dengan ketebalan media $20 \mathrm{Cm}$ dan hari kesembilan dengan presentase penurunan $71,24 \%$.

\section{PEMBAHASAN}

Hasil analisis univariat, diketahuinya kadar BOD pada perlakuan dengan menggunakan variasi ketebalan media dan lama kontak didapatkan bahwa penurunan yang tertinggi kadar BOD sebelum perlakuan adalah $229,5 \mathrm{mg} / \mathrm{l}$, dari 3 perlakuan tersebut yang paling tertinggi penurunannya adalah terletak pada perlakuan dengan ketebalan media $20 \mathrm{Cm}$ dan hari kesembilan dengan presentase penurunan 71,24\%. Hasil uji statistik Kruskall Wallis penurunan BOD yang sudah dibawah nilai ambang batas yaitu pada ketebalan $10 \mathrm{Cm}$ hari ke 6 dengan kadar BOD $82 \mathrm{mg} / \mathrm{lt}$ atau terjadi penurunan sebesar $64,27 \%$. Hasil penelitian ini menunjukkan bahwa proses biofilter memberikan pengaruh yang besar pada penurunan parameter BOD. Lama waktu kontak dan ketebalan media juga mempunyai pengaruh terhadap efektifitas biolfilter dalam mendegradasi bahan-bahan organik di dalam air limbah

\section{KESIMPULAN}

Hasil penelitian yang telah dilakukan, dapat diambil simpulan sebagai berikut :

1. Tidak ada perbedaan kadar BOD pada ketebalan media batu bata $10 \mathrm{Cm}, 20 \mathrm{Cm}$, $30 \mathrm{Cm}$ dan lama waktu kontak 3 hari, 6 hari dan 9 hari

2. Penurunan BOD yang paling efektif pada ketebalan $10 \mathrm{Cm}$ hari ke 6 dengan kadar BOD $82 \mathrm{mg} / \mathrm{lt}$ atau terjadi penurunan sebesar $64,27 \%$,

\section{SARAN}

1. Penelitian ini dapat digunakan sebagai media pembelajaran mahasiswa khususnya mata kuliah PAPLC dan merupakan alternative pengolahan limbah tahu dimasyarakat karena cukup efektif memperbaiki kualitas air limbah sehingga memenuhi baku mutu air limbah bagi usaha kegiatan pengolahan kedelai.

2. Untuk penelitian lebih lanjut dapat dikembangkan bakteri khusus yang mempunyai kemampuan yang lebih efektif dalam pengolahan air limbah tahu.

\section{DAFTAR PUSTAKA}

Astuti (2007). pengolahan air limbah industri tahu dengan menggunakan teknologi plasma. Tuhu Agung, R. Hanry Sutan Winata). Teknik lingkungan universitas pembangunan nasional "veteran" Jawa Timur. Jl. Ranggut Madya Gunung Anyar Surabaya. 60294.

Herlambang Ari, (2002). Teknologo pengolahan limbah cair tahu-tempe. http://www.kelair.bppt.go.id

Hidayah, (2007). Potensi Dan Pengaruh Tanaman Pada Pengelolaan Air Limbah Domestik Dengan Sistem Contructed Wetland. Jurnal Ilmiah Teknik Lingkungan.

Jenie, dkk, (2006). Pengolahan limbah pangan. Kanisius. Yogyakarta

KLH, Kementrian Lingkungan Hidup, No 32 tahun 2009, perlindungan dan pengelolaan lingkungan hidup. http://www.menlh.go.id

Nurhassan\&pramudyanto,(2007). Pengolahan Limbah Cair Industri Dengan 3 Metode Pengolahan.

Permen LH No 5 tahun 2014. Baku mutu air limbah/kegiatan pengelolaan kedelai. http://widyacipta.com/file.

Romayanto, Wiryanto dan Sajidan.2006. Pengolahan limbah domestik dengan aerasi dan penambahan bakteri Pseudomonas putidi. Jurnal Bioteknologi,

DOI.10.13057/biotek/c030202

Sugito (2013). Aplikasi Instalasi Pengolahan 
Air Limbah Biofilter untuk Menurunkan Kandungan Pencemar BOD, COD dan TSS di Rumah Sakit Bunda Surabaya. Jurnal. Universitas Adi Buana. Surabaya.

Said Nusa Idaman, (1999). Teknologi pengolahan air limbah tahu-tempe dengan proses biofilter anaerob dan aerob. Kelompok teknologi pengolahan air bersih dan limbah cair Direktorat teknologi lingkungan, Deputi bidang teknologi informasi, energi, material, dan lingkungan badan pengkajian dan penerapan teknologi. Jakata.

------------- (2005). Aplikasi Bio-Ball Untuk Pengolahan Air Limbah Pencucian Jean. JA Vol : 1 (2005), Jakarta.

-(2010). Pengelolaan air limbah dengan proses biofilter tercelup. BPPT. Jakarta.

--------- (2005). Uji Performance Biofilter Anaerobik Unggun Tetap Menggunakan Media Biofilter Sarang Tawon Untuk Pengolahan Air Limbah Rumah Potong Ayam. Kelompok Teknologi Pengelolaan Air Bersih dan Limbah Cair, Pusat Pengkajian dan Penerapan Teknologi Lingkungan, BPPT. Jurusan Kimia, Universitas Negeri Jakarta.

Sugiharto, (2008). Dasar-Dasar Pengelolaan Air Limbah. Universitas Indonesia Jakarta.

Tjokrokusumo (2009).Pengantar Konsep Teknologi Bersih Khusus Pengelolaan dan Pengolahan Air. STTL YLH. Yogyakarta. 